\title{
Culvert Effects on Stream and Stream-Side Salamander Habitats
}

\author{
James T. Anderson, Ryan L. Ward, J. Todd Petty, J. Steven Kite, and Michael P. Strager
}

\begin{abstract}
Road and stream intersections require a crossing that allows safe passage of water and vehicles. Culverts are normally used when roads cross small streams. Recently, passage of aquatic organisms through culverts has received increased attention. We used a geographic information system (GIS) analysis to determine the degree of salamander habitat fragmentation in Tucker and Randolph counties in West Virginia, USA. We visited state roads with culverts and categorized salamander barriers as complete, partial, or nonbarrier, based on outlet hang, culvert slope, and substrate. Complete barriers occurred at $\mathbf{5 5 . 0 \%}$ of the sites visited and partial barriers at $34.2 \%$. We found that $20.6 \%$ of the total stream length in the Dry Fork watershed and $18.4 \%$ in the Shavers Fork watershed were isolated by at least a partial barrier. Outlet hang height and the presence (or absence) of streambed substrate were the main determinants of stream salamander passage. Outlet hang was positively correlated with stream gradient and culvert slope. Culverts containing streambed substrate occurred on lower gradient streams, had lower culvert slope, and had a greater width compared to culverts lacking substrate. Solutions to facilitate movement of salamanders and other aquatic organisms are needed to maintain stream connectivity and provide mitigation opportunities.
\end{abstract}

Index Terms-Stream salamanders, culverts, habitat fragmentation, roads, streams, passage.

\section{INTRODUCTION}

Roads are a necessary component of human lives and a prominent feature on the landscape. The need for roads is not likely to change, and therefore as wildlife managers and environmental stewards we should strive to minimize their impacts on wildlife and their ecosystems. Practitioners of stream restoration have begun to develop ways to maintain stable road crossings and functioning streams [1]. However, the field of culvert installation to maintain geomorphic stability and provide passage of fish and other aquatic organisms is still in its infancy [2].

Salamanders have received little consideration for passage through culverts [2], [3]. Most studies focus on the passage of fish, including the development of computer software to

Manuscript received August 1, 2013; revised October 25, 2013. This work was supported in part by the West Virginia Division of Highways.

J. T. Anderson and J. T. Petty are with the Environmental Research Center and Division of Forestry and Natural Resources, West Virginia University, Morgantown, WV 26506 USA (e-mail: jim.anderson@mail.wvu.edu).

R. L. Ward was with the Division of Forestry and Natural Resources, West Virginia University, Morgantown, WV 26506 USA and is currently with AllStar Ecology, Fairmont, WV 26554 USA.

J. S. Kite is with the Department of Geology and Geography, West Virginia University, Morgantown, WV 26506.

M. P. Strager is with the Division of Resource Management, West Virginia University, Morgantown, WV 26506 USA. analyze culvert passage issues [2], [4], [5]. Excessive outlet hang of culverts is a common condition that blocks fish passage [2], [6]; however, culvert slope also can block fish passage [5]. The culvert outlet bottom should be below the outlet pool to prevent hanging barriers [7]. However, fish are able to use the outlet pool to swim and attain a sufficient velocity to overcome modest outlet hang [8]-[10]. Amphibians are weak swimmers compared to fish [11]. The reduced swimming ability of salamanders would most likely inhibit their ability to make use of outlet pools as areas to build up speed for jumping out of the water although salamanders on land can jump short distances to avoid predators [12].

Adult Axolotls (Ambystoma mexicanum) have lower swimming ability than most fishes [13]. Lower swimming abilities suggest that high water velocities through culverts would have a greater impact on salamanders than on fish During normal runoff conditions, water velocities in streams are typically $0-0.9 \mathrm{~m} / \mathrm{sec}$ near the channel bed and stream margins where most aquatic organisms live and travel [2]. Differences in water velocity in culverts compared to natural channels are likely to impede salamander passage [11].Flow velocities in culverts with gradients as low as $1-2 \%$ may exceed $1.2-1.5 \mathrm{~m} / \mathrm{sec}$ under normal runoff conditions without even constricting the channel width [2]. Velocities in culverts exceed extreme velocities in the natural channel that average $0.9-1.8 \mathrm{~m} / \mathrm{sec}$ during bankfull flows [2]. Terrestrial capabilities of salamanders could possibly allow them to navigate through or around culverts, but leaving their preferred habitat and crossing roads may make them vulnerable to predators and automobile mishaps [11].

Culverts need to be placed so the culvert bottoms mimic natural streambeds [14], because the physical nature of the bed material in a stream may be the most biologically significant factor affecting stream functions [15]. Salamanders use the channel substrate for refuge and foraging [16]. Culvert hang and slope as described above is also a major factor contributing to passage issues. Newly constructed roads that cross streams need to be built in a manner to not restrict any form of aquatic life movement, not just fish [3].

Previous research in the Appalachians has found that the presence of roads with culverts that were designated as being complete barriers to stream salamander movement was an important factor in dictating differences in salamander abundance, diversity, and richness at both the stream-level and the reach-level (i.e., above and below culverts) [3]. Indeed, abundance of Northern Two-lined (Eurycea bislineata), Appalachian Seal (Desmognathus monticola), Northern Spring (Desmognathus fuscus), and Mountain 
Dusky (Desmognathus ochrophaeus) Salamanders were all impacted by roads. All of these species except for Northern Two-lined Salamanders were negatively influenced by stream culverts. However, this study did not evaluate the extent of the barrier impact problem on amphibians in the Appalachians.

The objectives of our study were to:

1) Determine the extent of habitat fragmentation for salamanders by roads and culverts in the lower Shavers Fork watershed and Dry Fork watershed, West Virginia, USA;

2) Determine installation parameters of corrugated steel pipe culverts that will prevent excessive outlet hang and best promote the passage of stream and stream-side salamanders;

3) Determine installation parameters of circular and pipe arch culverts constructed of corrugated steel pipe that will allow for the retention of bedload material and best promote the passage of stream and stream-side salamanders.

\section{MATERIALS AND METHODS}

\section{A. Study Area}

We conducted culvert surveys in the lower Shavers Fork and the Dry Fork watersheds of the upper Cheat River basin (Fig. 1). The study area was located in Randolph and Tucker counties in eastern West Virginia [3], [5].

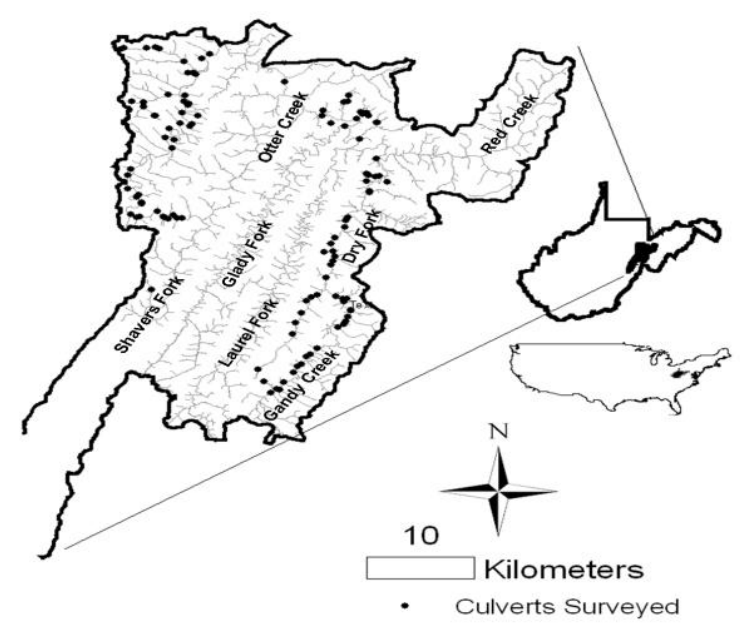

Fig. 1. Map of study area in the lower Shavers Fork and Dry Fork watersheds, West Virginia, USA 2003.Circles indicate state culverts where surveys were conducted.

Shavers Fork flows to the town of Parsons, West Virginia, where it combines with the Black Fork to form the Cheat River. Shavers Fork is a cold and cool water fishery with most tributaries consisting of high gradient mountain streams Surveys were conducted in the lower portion of the watershed, which contained an extensive state road network. The U.S. Forest Service or private landowners owned most roads in the upper portion of the watershed, and this area was excluded for this reason.

The Dry Fork flows near Parsons where it combines with the Blackwater River to form the Black Fork. Dry Fork maintains a cool-water fishery and a cold-water fishery in some sections. Major tributaries to Dry Fork include Gandy Creek, Laurel Fork, Glady Fork, and Red Creek. Laurel Fork and Glady Fork were excluded from the study due to a lack of state owned roads within their sub-watersheds. Red Creek was excluded from the study due to poor water quality. High gradient mountain streams characterized minor tributaries to Dry Fork and Gandy Creek. Otter Creek empties into lower Dry Fork from the Otter Creek Wilderness area.

The average winter temperature in the study area is $-0.5^{\circ} \mathrm{C}$ and the average summer temperature is $20.1^{\circ} \mathrm{C}$ [17], [18]. Average annual rainfall in the study area is $116 \mathrm{~cm}$ [17], [18]. Prevailing winds in the study area occur from the northwest and west [17], [18]. Elevations ranged from 518m to 1,472m. The most abundant geologic map units were the Pottsville group, Mauch Chunk group, Hampshire formation, and Chemung group [19].

\section{B. Methods}

Our study was conducted in three phases. First, we used geographic information system (GIS) analysis to create working maps for field crews. Next, we visited each culvert site and performed field surveys. Last, we conducted data analyses to interpret collected data.

We used ArcMap GIS ver. 8.2 software (Environmental Systems Research Institute, Redlands, California, USA) to determine the location of streams that drain at least 40.5 ha (100 acres). Then we added a layer of roads to find stream and road intersections. We used these layers to construct maps to assist field crews in finding stream crossings. Streams listed as impaired in 2003 according to the Clean Water Act Section 303d were excluded (West Virginia Department of Environmental Protection, unpubl. data). Streams with drainage areas less than 40.5ha, although ecologically important, were excluded because their small size offered fewer significant mitigation opportunities.

We conducted culvert surveys from June to November of 2003 following methods outlined in [5]. We visited each site to determine the crossing type (culvert, bridge, or ford). Only sites with culverts were surveyed. We recorded the type of each culvert, construction materials, length, and diameter or height and width. The active channel of the stream was defined as the portion of the channel that was lacking vegetation due to frequent water flows [6]. We took four measurements of the active channel width upstream of the culvert, and we took four measurements of bankfull width and bankfull depth at a typical riffle. We determined the length of stream reaches to be surveyed by multiplying the mean active channel width by 30 . We used a minimum length of $30 \mathrm{~m}$ and a maximum length of $100 \mathrm{~m}$ to limit reach lengths. The culvert generally was located in the center of each stream study reach. Where a culvert occurred near a stream mouth, we surveyed the entire downstream reach if it was not long enough to meet the total desired reach length.

We surveyed the longitudinal profile of the stream in the study reach from the head of the first riffle to the head of the last riffle. We recorded elevations at the following points: 
head of upstream riffle, inlet, outlet, deepest part within $2 \mathrm{~m}$ of outlet, deepest part of outlet pool, tailwater control, the active channel margin at the tailwater control, head of downstream riffle, and additional slope breaks [6]. We collected additional habitat measurements, including estimation of the percent canopy of the overstory, shrub, and herbaceous layers for each bank both upstream and downstream, presence or absence of continuous suitable salamander (>40 mm diameter) substrate above, below, and inside culverts, and completion of Environmental Protection Agency (EPA) habitat assessment forms [20] for up and downstream.

\section{Data Analysis}

We conducted surveys on all culverts on state roads and the full data set was used to analyze the barrier effects as a whole on the landscape. We considered any culvert with an outlet hang over $0.10 \mathrm{~m}$ a complete barrier for salamanders [3]. Outlet hangs of $0.05-0.10 \mathrm{~m}$ were considered partial barriers. Culverts with outlet hangs under $0.05 \mathrm{~m}$, but lacking continuous substrate were considered partial barriers. Only if a culvert had an outlet hang under $0.05 \mathrm{~m}$ and continuous substrate, did we consider it passable (Fig. 2). We used ArcMap GIS ver. 9.0 software (Environmental Systems Research Institute, Redlands, California, USA) to determine the length of stream reaches fragmented by complete and partial barrier culverts. We excluded Otter Creek from analysis of fragmentation because it is wilderness area and lacks an active road system. We used a G-test of association to test if the barrier types observed differed from expected values and for comparison of barrier types between watersheds [21].

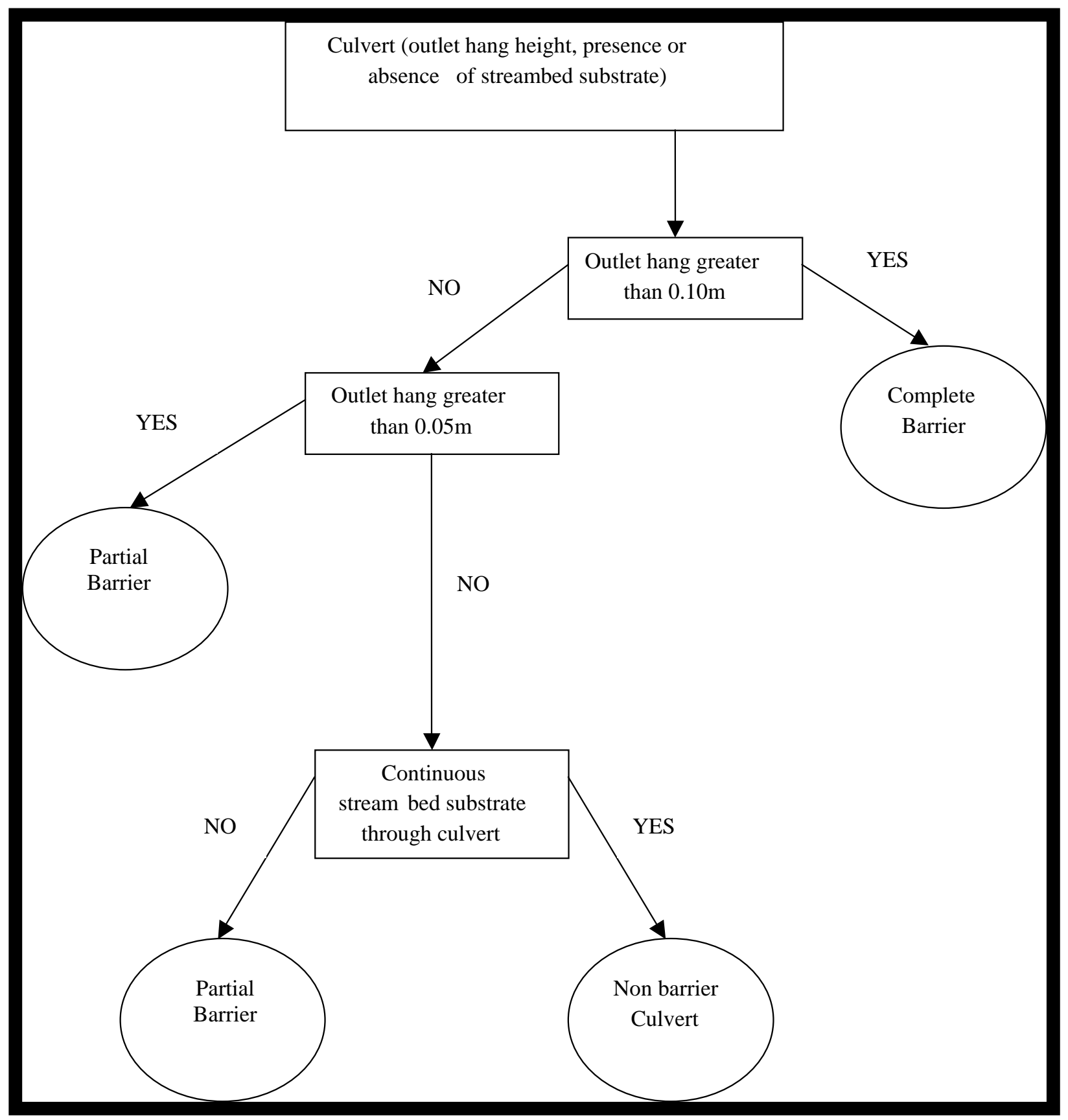

Fig. 2. Decision tree used to determine barrier status of culverts for stream salamanders in the lower Shavers Fork and Dry Fork watersheds, West Virginia, USA. Culverts were classified as complete barriers $(n=66)$, partial barriers $(n=41)$, and nonbarriers $(n=13)$. 
Corrugated steel pipe was the most common construction material used for culverts in the study area. Because of their numbers, analyses of culvert parameters were restricted to culverts constructed of corrugated steel pipe. Some stream crossings contained multiple culvert barrels. Because of the low number of sites with multiple barrels, they were removed from analyses of culvert parameters. We used linear regression to examine relations between hang height and stream gradient, culvert length, and culvert slope. We conducted analyses of bedload retention only on sites with continuous substrate upstream of the culvert. This restriction was intended to rule out bedrock streams that were bedload limited. We used a G-test to compare circular and pipe arch culverts, and their ability to retain stream bedload [21]. We used t-tests, assuming equal variances, to compare culvert variables for culverts with and without continuous substrate. We analyzed the variables of circular culverts separately from pipe arch culverts, because different shapes likely influenced hydraulic forces. We considered tests to be significant at $P<0.05$ and did not transform data because normality was not violated [22]. Comparisons we conducted included culvert variables (slope and diameter/width), stream variables (gradient), and ratios of culvert variables versus stream variables (culvert diameter/width versus active channel width, culvert slope versus stream gradient, and culvert cross-sectional area versus bankfull cross-sectional area).

\section{RESULtS}

\section{A. Culvert Surveys}

A total of 120 culvert sites was surveyed in the Dry Fork ( $n$ $=68)$ and Shavers Fork $(n=52)$ watersheds. Single culverts occurred at 116 sites, while the remaining four sites had double culverts. Circular culverts were the most common type, occurring at 66 sites. Pipe arch culverts were the second most abundant type, occurring at 36 sites. Box culverts occurred at 13 sites. Combinations of box and circular culverts occurred at five sites. These combined culverts consisted of old stone box culverts that were lengthened with corrugated steel or concrete pipe culverts when the roadway was widened. Corrugated steel pipe was the most common construction material occurring at 94 sites, and concrete was used at 20 sites. The remaining six sites were made of stone or stone and corrugated steel pipe combinations.

\section{B. Habitat Fragmentation}

Culverts were likely to create barriers to salamanders as salamander movement conditions were classified as complete barriers at $55.0 \%$, partial barriers at $34.2 \%$, and unrestricted passage at $10.8 \%$ of culverts surveyed (Fig. 3; Ward 2005) ( $n$ $=120, G=38.90, d f=2, P<0.001)$. Culverts in the Shavers Fork watershed were more likely to be complete barriers than in the Dry Fork watershed (Fig. 3) $(G=14.32, d f=2, P<$ $0.001)$. Barriers isolated $20.6 \%$ of the total lengths of stream draining > 40.5ha in the Dry Fork watershed and $17.4 \%$ in the Shavers Fork watershed (Table I).

\section{Outlet Hang}

Hang height was correlated with stream gradient for corrugated steel pipe culverts $\left(n=90, R^{2}=0.185, P<0.001\right)$ (Fig. 4). A correlation also existed between hang height and culvert slope $\left(R^{2}=0.096, P=0.002\right)$. A weak correlation was found between culvert length and hang height $\left(R^{2}=0.056, P\right.$ $=0.02$ ).

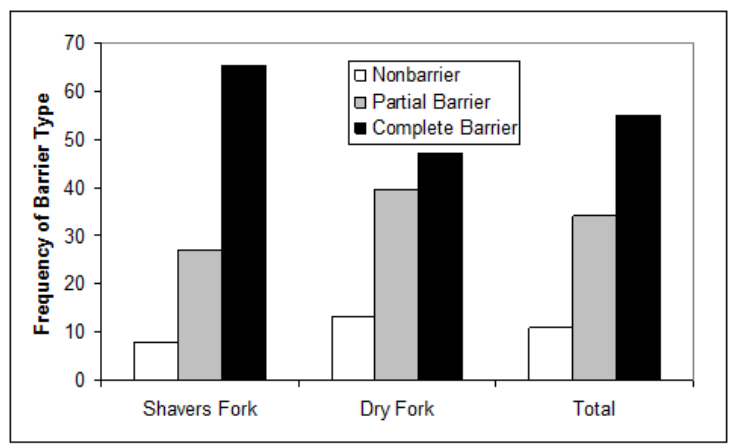

Fig. 3. Frequency of barrier categories for salamanders in the lower Shavers Fork $(n=52)$ and Dry Fork $(n=68)$ watersheds, West Virginia, USA 2003.

TABLE I: LENGTHS OF STREAM AFFECTED BY BARRIER CULVERTS LOCATED ON STATE ROADS IN THE DRY FORK AND SHAVERS FORK WATERSHEDS, WEST VIRGINIA, USA 2003

\begin{tabular}{ccccc}
\hline & & \multicolumn{3}{c}{ Isolated Stream Segments $(\mathbf{k m})$} \\
\cline { 3 - 5 } & $\begin{array}{c}\text { Total } \\
\text { Stream } \\
\text { Length } \\
(\mathbf{k m})\end{array}$ & $\begin{array}{c}\text { Complete } \\
\text { Barriers }\end{array}$ & $\begin{array}{c}\text { Partial } \\
\text { Barriers }\end{array}$ & Total \\
& & & & \\
\hline Dry Fork & $341.5^{\mathrm{a}}$ & 42.7 & 27.6 & 70.3 \\
& & $(12.5 \%)$ & $(8.1 \%)$ & $(20.6 \%)$ \\
Lower & & & & \\
Shavers & 276 & $(11.6 \%)$ & $(6.8 \%)$ & $(17.4 \%)$ \\
Fork & & & & \\
\hline
\end{tabular}

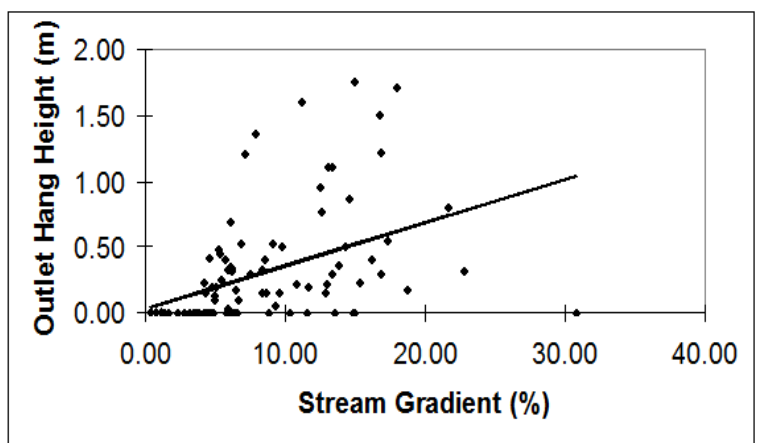

Fig. 4. Linear regression showing the relation between outlet hang height and stream gradient for 116 single barrel culverts in the Dry Fork and Shavers Fork watersheds, West Virginia, USA 2003.

\section{Continuous Substrate}

Of the 120 culverts surveyed, upstream reaches had continuous substrate in $87.3 \%$ of surveyed sites, and downstream reaches had continuous substrate in $85.6 \%$ of the sites. Only $17.9 \%$ of the sites had continuous substrate throughout the entire culvert length (Fig. 5). Culverts tended to create breaks in the stream channel material $(n=120, G=$ 61.49, $d f=1, P<0.001)$.

We performed analyses on a total of 53 circular culverts $(9$ with continuous substrate) and 29 pipe arch culverts ( 5 with continuous substrate). No difference was found between the proportion of circular culverts with substrate (17.0\%) and the 
proportion of pipe arches with substrate $(17.2 \%)(n=82, G=$ $0.31, d f=1, P=0.54)$.

Culvert slopes were lower for culverts with continuous substrate compared to those lacking substrate (Table II). Culvert diameters were greater for culverts with continuous substrate compared to those without continuous substrate (Table II). Culverts with continuous substrate occurred on streams with significantly less gradient than culverts without continuous substrate (Table II). There was no difference for stream gradient of pipe arches, but pipe arches with continuous substrate were wider than culverts lacking continuous substrate (Table III).

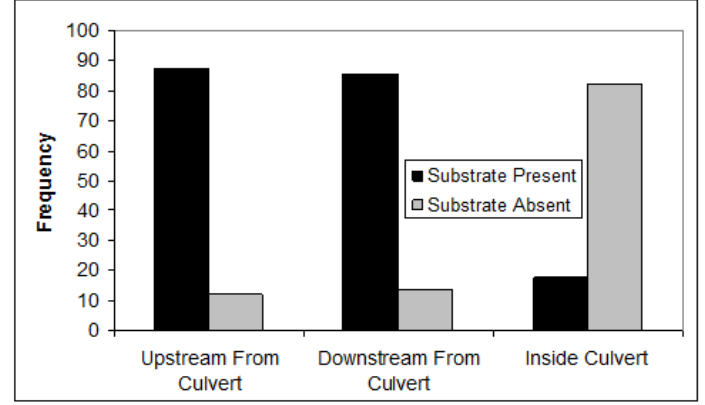

Fig. 5. Graph showing frequency distribution of areas with continuous substrate at culvert sites for 120 culverts in the Dry Fork and Shavers Fork watersheds, West Virginia, USA 2003.

TABlE II: Results of ANalyses on Retention of Streambed Substrate Performed on 53 Single, Circular Culverts Constructed of CORRUGATED STEEL PIPE IN THE DRY FORK AND SHAVERS FORK WATERSHEDS, WEST VIRGINIA, USA 2003

\begin{tabular}{|c|c|c|c|c|c|c|}
\hline \multirow[b]{2}{*}{ Variable } & \multicolumn{2}{|c|}{ No Substrate } & \multicolumn{2}{|c|}{ Substrate } & \multirow[b]{2}{*}{$t$-test } & \multirow[b]{2}{*}{$P$-value } \\
\hline & Mean & SE & Mean & SE & & \\
\hline Culvert Diameter vs. Active Channel Width & 0.60 & 0.05 & 0.66 & 0.07 & -0.61 & 0.271 \\
\hline Culvert Slope vs. Stream Gradient & 0.69 & 0.06 & 0.51 & 0.09 & 1.43 & 0.079 \\
\hline Bankfull X-sect. vs Culvert X-sect. Area & 1.12 & 0.17 & 1.20 & 0.51 & -1.12 & 0.134 \\
\hline Culvert Slope $\mathrm{a}^{\mathrm{a}}$ & 6.81 & 0.58 & 3.01 & 0.81 & 2.84 & 0.003 \\
\hline Stream Gradient ${ }^{\mathrm{a}}$ & 10.86 & 0.91 & 6.56 & 1.46 & 2.03 & 0.024 \\
\hline Culvert Diameter $^{\mathrm{a}}$ & 1.15 & 0.06 & 1.87 & 0.30 & -3.86 & 0.001 \\
\hline
\end{tabular}

asignificant alpha level $=0.05$.

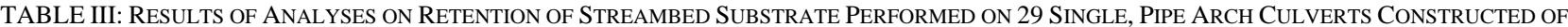
CORRUGATED STEEL PIPE IN THE DRY FORK AND SHAVERS FORK WATERSHEDS, WEST VIRGINIA, USA 2003

\begin{tabular}{|c|c|c|c|c|c|c|}
\hline \multirow[b]{2}{*}{ Variable } & \multicolumn{2}{|c|}{ No Substrate } & \multicolumn{2}{|c|}{ Substrate } & \multirow[b]{2}{*}{$t$-test } & \multirow[b]{2}{*}{$P$-value } \\
\hline & Mean & $\mathbf{S E}$ & Mean & SE & & \\
\hline Culvert Width vs. Active Channel Width & 0.93 & 0.06 & 1.07 & 0.13 & -0.86 & 0.1982 \\
\hline Culvert Slope vs. Stream Gradient & 0.74 & 0.08 & 0.47 & 0.13 & 1.37 & 0.0906 \\
\hline Bankfull X-sect. vs Culvert X-sect. Area & 1.70 & 0.23 & 1.99 & 0.29 & -0.57 & 0.2872 \\
\hline Culvert Slope & 4.54 & 0.50 & 3.18 & 1.21 & 1.11 & 0.1383 \\
\hline Stream Gradient & 7.21 & 0.83 & 5.79 & 1.12 & 0.75 & 0.2296 \\
\hline Culvert Width $^{\mathrm{a}}$ & 1.88 & 0.13 & 2.64 & 0.34 & -2.39 & 0.0120 \\
\hline
\end{tabular}

\section{DISCUSSION}

\section{A. Habitat Fragmentation}

The majority of culverts surveyed were complete or partial barriers to stream salamanders $(89 \%)$. These sites most likely prevented the movement of salamanders at all or most flow conditions. Complete barriers occurred at a greater frequency than expected from chance alone. A higher percentage of culverts in the lower Shavers Fork watershed were complete barriers compared to the Dry Fork watershed. One possible 
explanation for this result is the number of high gradient streams in the lower Shavers Fork watershed because of steeper topography. The Dry Fork watershed had more low gradient streams, especially in the Gandy Creek subwatershed. Extra consideration must be given to placing culverts on high gradient streams (>8\%). Upstream movement of salamanders and connectivity of salamander habitats are important for the persistence of populations over time [23], [24].

Culverts isolated headwater streams from downstream areas. Headwater streams are the most important habitat for stream salamanders and have the highest densities of salamanders [25], [26]. In the Dry Fork watershed, 20.6\% of the total stream length was isolated from colonization sources. In the Shavers Fork watershed, $18.4 \%$ of the total stream length was isolated. Isolated streams consisted of low order headwater streams separated from the mainstem of each river. Salamanders move into these areas to exploit resources available in less hydraulically stable streams lacking fish populations [11].

Culverts with hang heights of $\geq 0.10 \mathrm{~m}$ were considered complete barriers to stream salamanders. Indeed, this hang height has an influence on salamander communities [3]. We hypothesized that small body sizes and weak swimming abilities probably prevent stream salamanders from overcoming large outlet hangs. Fish can overcome larger hang height because of their ability to use the outlet pool to gain speed for jumping [8]-[10]. Culverts with hang heights of $0.05-0.10 \mathrm{~m}$ were considered partial barriers. These hang heights were only estimates we made for the passage of adult stream salamanders. We are confident that stream salamanders cannot overcome hang heights $\geq 0.10 \mathrm{~m}$, but lower heights possibly might be overcome if the right conditions existed. Passage for larval salamanders would likely still be prevented at any outlet hang height. Older life stages of salamanders are more likely to undergo upstream movements [27]. However, many salamander species have larval stages longer than a year [12], and salamanders often undergo upstream movement to find suitable wintering locations [28], [29]. Hang heights under $0.05 \mathrm{~m}$ were considered passable by adult salamanders even though larval stream salamanders would not be likely to overcome any hang at the outlet.

Culverts that prevent up and downstream movements of salamanders affect the structure of populations and the ability of individuals to locate wintering sites [27]-[29]. Also, some salamanders use streambeds as movement corridors [30]. Workers should try to minimize outlet hang in crossing structures. This minimization may require the building of a bridge on a high gradient stream and avoiding the use of a culvert altogether.

\section{B. Substrate Effects}

The presence of continuous streambed substrate throughout the culvert was required to categorize a culvert as a nonbarrier. Streambed material creates variations in the flow velocity that allow salamanders to move upstream [11]. To pass a culvert the salamander had to be able to enter the culvert barrel and then negotiate the entire culvert length. Retention of streambed material allows salamanders to overcome high velocities found inside culverts.

Culverts in the study area are serving poorly to retain bed material and prevent breaks in the substrate. Only $17.9 \%$ of the sites visited contained continuous substrate through the culvert while most upstream reaches (87.3\%) and downstream reaches $(85.6 \%)$ had continuous substrate. These results show a failure of culverts to mimic natural channels and show a need for better culverts and installation methods. If dimensions and placement of corrugated steel pipe culverts can be done properly to prevent breaks in the stream substrate, they may provide a low cost alternative to other options such as bridges and concrete culverts that provide adequate substrate.

Circular culverts with continuous substrate had larger diameters than culverts lacking continuous substrate. A similar trend was observed in the width of pipe arches. A larger diameter or width prevents pooling at the inlet of a culvert and subsequent deposition of bed material before entering the culvert [2]. Within the study area $91 \%$ of aggraded reaches at culverts were at least partially caused by low conveyance [31]. Small diameters or widths also constrict the flow of streams, which can cause increased water velocity [2]. Wider culverts better simulate natural stream conditions [2]. Larger culverts also prevent the failure of fill dirt used in the roadbed that can be a source of sedimentation in streams [32]. Wide culverts tend to be found on larger streams, and these large streams tend to be lower in gradient and able to successfully retain substrate. More attention should be given to smaller streams because of their overall importance and the historical lack of consideration given to them.

\section{Management Implications}

Culverts can be modified to benefit aquatic organisms [10]. Velocities have been slowed with the addition of corrugations and baffles inside culverts, which increase roughness [6]. Baffles can improve fish passage and show good durability [8], [10]. Problems with baffles include high cost, difficulty in fabrication, sedimentation, debris jams, icing, and increased turbulence through the culvert [7], [10], [14]. The increased turbulence created by baffles may be negative for salamanders. However, if baffles trap some sediment this might provide a suitable surface for salamanders to use during passage. Weirs can be used to adjust stream gradients at the inlet and outlets of culverts, compensating for large drops and hydraulic forces [6]. If water is pooled into the culvert outlet this would help salamanders enter culverts.

Most research on culverts and barriers has concentrated on fish. Swimming abilities of salamanders is relatively unknown compared to most fish species. More data on the abilities of salamanders would better allow for the analysis of barriers. Future research needed includes the effects of fragmentation on stream salamander populations and population genetics. Also more studies are needed on the movement of stream salamanders. Detailed studies are needed on distances moved, reasons for movement, and timing of movement for different life stages of salamanders. Research on culvert designs should include ways to increase 
roughness and preventing increased water velocities. New types of culvert are needed to accommodate passage of a wider range of aquatic organisms. When designing new culverts, consideration should be given to cost and ease of installation. Development of methods to retrofit existing culverts to eliminate passage problems would provide a more cost effective alternative to replacement of culverts that are still structurally sound.

\section{ACKNOWLEDGMENT}

Field assistance was provided by Ira Poplar-Jeffers, Pat Kish, and Josh White. We thank Norse Angus with the West Virginia Division of Highways for his support of this project and for reviewing this manuscript. This is scientific article No. 3190 of the West Virginia University Agricultural and Forestry Experiment Station.

\section{REFERENCES}

[1] P. A. Johnson, "Incorporating road crossings into stream and river restoration projects," Ecological Restoration, vol. 20, pp. 270-277, 2002.

[2] T. L. Sylte, "Providing for stream function and aquatic organism passage: an interdisciplinary design," Stream Notes, pp. 1-4, January 2002.

[3] R. L. Ward, J. T. Anderson, and J. T. Petty, "Effects of road crossings on stream and streamside salamanders," Journal of Wildlife Management, vol. 72, pp. 760-771, 2008.

[4] M. J. Furniss, S. Firor, and M. Love, "Fish Xing 2.0 software and learning system for the analysis of fish migration through culverts," Stream Notes, pp. 1-4, July 2000.

[5] I. O. Poplar-Jeffers, J. T. Petty, J. T. Anderson, S. J. Kite, M. P. Strager, and R. H. Fortney, "Culvert replacement and stream habitat restoration: implications from brook trout management in an Appalachian watershed, U.S.A," Restoration Ecology, 2009.

[6] R. N. Taylor and M. Love, "Fish passage evaluation at stream crossings," California Salmonid Stream Habitat Restoration Manual, part IX, 2003.

[7] G. M. Fitch, "Nonanadromous fish passage in highway culverts," Virginia Transportation Research Council Report VTRC 96-R6, pp. $18,1995$.

[8] T. J. McClellan, "Fish passage through highway culverts," United States Department of Transportation, Federal Highway Administration and Oregon State Game Commission, Portland, Oregon, pp. 16, 1970.

[9] P. D. Powers, "Analysis of barriers to upstream fish migration," M. S. Thesis, Washington State University, Pullman, Washington, 1984.

[10] V. Blevins and R. F. Carlson, "Retrofit design of drainage structures for improved fish passage: literature review," Water Research Center, Institute of Northern Engineering, University of Alaska Fairbanks, Report No. AK-RD-89-02, pp. 38, 1988.

[11] S. D. Jackson, "Ecological considerations in the design of river and stream crossings," in 2003 Proc. the International Conference on Ecology and Transportation, Center for Transportation and the Environment, North Carolina State University, Raleigh, North Carolina, 2003, pp. 20-29.

[12] N. B. Green and T. K. Pauley, Amphibians and Reptiles in West Virginia, University of Pittsburgh Press, Pittsburgh, Pennsylvania, 1987.

[13] K. D'Aout and P. Aerts, "Kinematics and efficiency of steady swimming in adult axolotls (Ambystoma mexicanum)," Journal of Experimental Biology, vol. 200, pp. 1863-1871, 1997.

[14] C. O. Baker and F. E. Votapka, "Fish passage through culverts," United States Department of Agriculture, Forest Service Technology and Development Center, Report No. FHWA-FL-90-006, pp. 76, 1990.

[15] K. W. Cummins, "Structure and function of stream ecosystems," BioScience, vol. 24, pp. 631-641, 1974.

[16] A. L. Moore, C. E. Williams, T. H. Martin, and W. J. Moriarity, "Influence of season, geomorphic surface, and cover item on capture, size, and weight, of Desmognathus ochrophaeus and Plethodon cinereus in Allegheny Plateau riparian forests," American Midland Naturalist, vol. 145, pp. 39-45, 2001.
[17] C. K. Losche and W. W. Beverage, "Soil survey of Tucker County and part of northern Randolph County, West Virginia," United States Department of Agriculture, Soil Conservation Service and Forest Service, 1967.

[18] R. E. Pyle, W. W. Beverage, T. Yoakum, D. P. Amick, W. F. Hatfield, and D. E. McKinney, "Soil survey of Randolph County area, main part, West Virginia," United States Department of Agriculture, Soil Conservation Service and Forest Service, 1982.

[19] D. H. Cardwell, R. B. Erwin, and H. P. Woodward, "Geologic map of West Virginia," West Virginia Geological and Economic Survey. 1:250,000 scale, West Virginia Department of Environmental Protection and United States Geologic Survey Water Resources Division, 1968.

[20] M. T. Barbour, J. Gerritsen, B. D. Snyder, and J. B. Stribling, "Rapid bioassessment protocols for use in streams and wadeable rivers: periphyton, benthic macroinvertebrates and fish, second edition," Environmental Protection Agency, Office of Water, Report EPA 841-B-99-002, pp. 339, 1999.

[21] R. R. Sokal and F. J. Rohlf, 1994. "Biometry: the principles and practices of statistics," in Biological Research, 3rd ed. W. H. Freeman and Company, New York, 1994.

[22] R. L. Ward, "The effects of roads and culverts on stream and stream-side salamander communities in eastern West Virginia," M. S. Thesis, West Virginia University, Morgantown, West Virginia, pp. 198, 2005.

[23] W. H. Lowe and D. T. Bolger, "Local and landscape predictors of salamander abundance in New Hampshire headwater streams," Conservation Biology, vol. 16, pp. 183-193, 2002.

[24] W. H. Lowe, "Linking dispersal to local population dynamics: a case study using a headwater salamander system," Ecology, vol. 84, pp. 2145-2154, 2003.

[25] W. J. Resetarits, "Competitive asymmetry and coexistence in size-structured populations of brook trout and spring salamanders," Oikos, vol. 73, pp. 188-198, 1995.

[26] Technical Report: Ohio's Primary Headwater Streams-Fish and Amphibian Assemblages, Ohio EPA, Division of Surface Water, Columbus, Ohio, pp. 41, 2002.

[27] R. C. Bruce, "Upstream and downstream movements of Eurycea bislineata and other salamanders in a southern Appalachian stream," Herpetologica, vol. 42, pp. 149-155, 1986.

[28] R. E. Ashton, "A study of movement, home range, and winter behavior of Desmognathus fuscus (Rafinesque)," Journal of Herpetology, vol. 9, pp. 85-91, 1975.

[29] R. E. Ashton and P. S. Ashton, "Movements and winter behavior of Eurycea bislineata (Amphibia, Urodela, Plethodontidae)," Journal of Herpetology, vol. 12, pp. 295-298, 1978.

[30] J. P. Gibbs, "Amphibian movements in response to forest edges, roads, and streambeds in southern New England," Journal Wildlife Management, vol. 62, pp. 584-589, 1998.

[31] J. A. White, "Geomorphic analysis of stream crossings in a portion of the upper Cheat River basin,” M. S. Thesis, West Virginia University, Morgantown, West Virginia, pp. 71, 2004..

[32] W. Saltzman and R. O. Koski, "Fish passage through culverts," Oregon State Game Commission Special Report, Portland, Oregon, pp. 8, 1971.

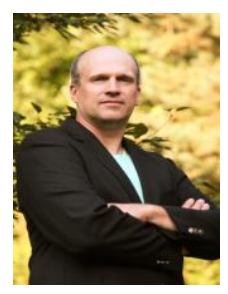

James (Jim) T. Anderson is a professor of Wildlife and Fisheries Resources, Davis-Michael professor of Forestry and Natural Resources, and the director of the Environmental Research Center at West Virginia University. He earned a B.S. in wildlife from the University of Wisconsin-Stevens Point, an M.S. in range and wildlife management through the Caesar Kleberg Wildlife Research Institute at Texas A\&M University-Kingsville, and a Ph.D. in wildlife science from Texas Tech University. He has been at West Virginia University since 1999. Dr. Anderson's research interests include wildlife-habitat relations, restoration ecology, and wetland and riparian ecology and management.

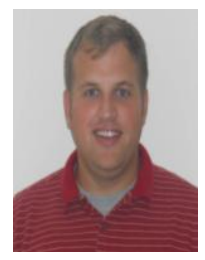

Ryan Ward is a senior environmental scientist and owner with the consulting firm All Star Ecology, LLC. He earned a B.S. in wildlife management from Texas Tech University in 2003 and a M.S. in wildlife resources from West Virginia University in 2005.Mr. Ward's work focuses on wetland and stream restoration and regulatory compliance for private, non-profit, and government organizations. 


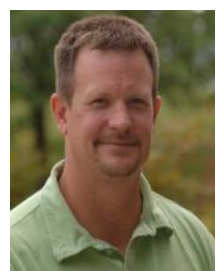

Todd Petty is a professor of Wildlife and Fisheries Resources at West Virginia University. He earned a B.A. in biology from the University of Virginia and an M.S. and Ph.D. in forest resources from the University of Georgia. He has been at West Virginia University since 2000. Dr. Petty's research interests include stream and river ecology and watershed modeling and restoration.

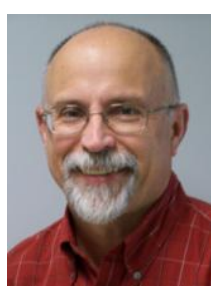

J. Steven (Steve) Kite is the chair of the Department of Geology and Geography at West Virginia University. He earned a B.S. in geology from the James Madison University, an M.S. in geological sciences at the University of Maine-Orono, and a Ph.D. in geography and geology from the University of Wisconsin-Madison. He has been at WVU since 1983 Dr. Kite's research interests include geomorphology, late Cenozoic landscape genesis, and geoarcheology.

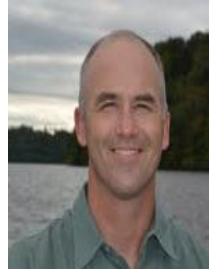

Michael P. Strager is an associate professor of Spatial Analysis, Division of Resource Management at West Virginia University. He earned a B.S. degree from Penn State University and M.S. and Ph.D. degrees from West Virginia University. Dr. Strager specializes in applying geospatial technologies for managing natural resources. He has been a lead developer on many spatial decision support systems that enable users to evaluate alternative management scenarios covering topics such as watershed management, sustainable forestry, wildlife modeling and landscape conservation. 